\title{
Suplementasi Urea dan Tepung Ikan Meningkatkan Fermentabilitas Ransum Berbasis Kulit Buah Kakao pada Kambing
}

\author{
(Urea and Fish Meal Supplementation Improved Cacao Pod Husk Based Diet \\ Fermentability in Goat)
}

\author{
Puastuti W, Yulistiani D \\ Balai Penelitian Ternak, PO Box 221, Ciawi, Bogor 16002 \\ wisri_puast@yahoo.com; dwiyulistiani@yahoo.com
}

\begin{abstract}
The objective of the study was to evaluate cacao pod husk based on diet fermentability which supplemented with urea and fish meal as grass basal diet substitution for goat. Cacao pod husk diet was offered in the form silage by adding $10 \%$ rice bran. The diet treatment as follows: $\mathrm{R}=$ Grass + concentrate R; S = Cacao pod silage + concentrate S; SU = Cacao pod silage + concentrate SU; SI $=$ Cacao pod silage + concentrate SI; and SUI $=$ Cacao pod silage + concentrate SUI. Rations were evaluated in randomized complete block design using 20 heads male kids of Ettawah crossed bred. Dry matter digestibility of rations S, SU, SI, and SUI was $62.11-67.45 \%$ and was not significantly different $(\mathrm{P}>0.05)$ compared to ration $\mathrm{R}$ which was $69.83 \%$. Ration $\mathrm{S}$ had $34.5 \%$ lower NDF digestibility compared to ration R. But R was compared to ration SI and SUI, this supplementation was able to increase the NDF digestibility by 16.3 and $26.4 \%$. The significant increase was also occurred in ADF digestibility. The average of total VFA was in the ranges 134.1-151.0 mM in rations S, SU, SI, SUI whereas in rations R was $132.73 \mathrm{mM}$. It can be concluded that ration based of cacao pod husk silage supplemented by urea-fish meal able to replace rations based of grass with similar in diet digestibility and ability to supply energy.
\end{abstract}

Key Words: Rumen Fermentation, Urea, Fish Meal, Cacao Pod Husk

\begin{abstract}
ABSTRAK
Penelitian bertujuan untuk mengevaluasi fermentabilitas ransum berbasis silase kulit buah kakao (KBK) yang disuplementasi urea dan tepung ikan sebagai pengganti ransum berbasis rumput pada kambing. Pemberian KBK dalam bentuk silase dibuat dengan menambah $10 \%$ dedak padi dan difermentasi secara anaerob. Perlakuan ransum percobaan adalah $\mathrm{R}=\mathrm{Rumput}+$ konsentrat $\mathrm{R} ; \mathrm{S}=$ Silase KBK + konsentrat S; SU = Silase KBK + konsentrat SU; SI = Silase KBK + konsentrat SI; dan SUI = Silase KBK + konsentrat SUI. Pengujian ransum digunakan rancangan acak kelompok menggunakan 20 ekor kambing jantan Peranakan Ettawah (PE). Nilai kecernaan BK dari ransum S, SU, SI dan SUI sebesar 62,11-67,45\% tidak berbeda nyata $(\mathrm{P}>0,05)$ dengan ransum $\mathrm{R}$ sebesar $69,83 \%$. Ransum S menghasilkan kecernaan SDN yang lebih rendah 34,5\% dari ransum R, namun bila dibandingkan dengan SI dan SUI mampu meningkatkan kecernaan SDN masing-masing sebesar 16,3 dan $26,4 \%$. Kenaikan yang nyata juga dihasilkan dari kecernaan SDA. Nilai rata-rata VFA total berkisar 134,1-151,0 mM pada ransum S, SU, SI, SUI dan sebesar 132,73 mM pada ransum R. Dapat disimpulkan bahwa ransum berbasis silase KBK yang disuplementasi campuran urea dan tepung ikan dapat menggantikan ransum berbasis rumput dengan kecernaan dan kemampuan menghasilkan energi yang setaraf.
\end{abstract}

Kata Kunci: Fermentasi Rumen, Urea, Tepung Ikan, Kulit Buah Kakao

\section{PENDAHULUAN}

Pemanfaatan kulit buah kakao (KBK) sebagai pakan ternak ruminansia, terutama kambing sudah banyak dilakukan di wilayah sentra perkebunan kakao (cokelat) yang 
menyebar hampir di seluruh provinsi di Indonesia, kecuali DKI Jakarta karena tidak memiliki perkebunan kakao. Selain dimanfaatkan sebagai pakan, KBK juga dapat digunakan sebagai pupuk organik. Penggunaan KBK sebagai pakan terutama dilakukan pada musim panen buah kakao. Hal ini karena peternak memberikan KBK segar dengan cara dicacah sebagai pakan tambahan atau sebagai pengganti rumput. Bila ditinjau dari komposisi nutriennya, KBK berpotensi untuk digunakan sebagai pakan sumber energi dimana KBK mengandung protein kasar antara 6,80-13,78\%, serat deterjen netral (SDN) 55,30-73,90\% dan serat deterjen asam (SDA) 38,31-58,98\% (Puastuti \& Yulistiani 2011; Adamafio 2013; Puastuti \& Susana 2014). Namun, KBK dilaporkan memiliki faktor pembatas berupa lignin 14,70-23,65\% (Rinduwati \& Ismartoyo 2002; Zain 2009; Daud et al. 2013), tanin 0,84-5,1\% (Rinduwati \& Ismartoyo 2002; Mensah et al. 2012) dan theobromine 0,15-0,40\% (Adamafio 2013). Dilaporkan lebih lanjut bahwa keberadaan senyawa antinutrisi dapat mengurangi daya cerna suatu bahan pakan.

Memperhatikan kandungan serat, adanya lignin dan tanin serta theobromine pada KBK maka pemanfaatkan KBK memerlukan pengolahan untuk meningkatkan ketersediaan nutriennya, kecernaan dan mengurangi senyawa antinutrisi dari KBK. Beberapa metode pengolahan bahan produk samping pertanian antara lain secara fermentasi, amoniasi ataupun silase menghasilkan nilai kecernaan yang bermacam-macam. Nilai kecernaan KBK tanpa diolah sebesar $22 \%$ dan tidak berbeda setelah diolah dengan beberapa taraf Aspergillus niger (18,6-25,1\%) (Hardana et al. 2013).

Salah satu pengolahan KBK dengan cara difermentasi tanpa starter mikroba, dapat dilakukan dengan imbuhan sumber energi sebagai stimulator mikroba indigenous dari bahan yang difermentasi, yang dikenal dengan proses silase. Pada proses silase, mikroba yang berperan adalah bakteri asam laktat yang mampu mempertahankan kualitas bahan dan meningkatkan daya simpan (Puastuti \& Susana 2014). Selanjutnya untuk meningkatkan kecernaan pakan pada ternak ruminansia dapat pula dilakukan dengan pemberian suplemen yang dapat menstimulasi proses fermentasi mikroba di dalam rumen. Urea dan tepung ikan masing-masing mampu menyediakan nitrogen dan asam amino yang berguna dalam mendukung sintesis protein mikroba sehingga aktivitas kecernaan di dalam rumen meningkat. Sifat urea yang mudah larut akan menyediakan nitrogen yang mudah tersedia di dalam rumen. Tepung ikan dengan kandungan protein tinggi mampu menyediakan asam amino untuk mendukung sintesis protein mikroba. Menurut Puastuti (2009) manipulasi ekosistem rumen dapat dilakukan melalui pendekatan pengolahan pakan dan melalui pemberian pakan tambahan yang dapat menstimulasi pertumbuhan dan aktivitas mikroba rumen guna meningkatkan kecernaan dan efisiensi penggunaan pakan. Penelitian ini bertujuan untuk mengevaluasi fermentabilitas ransum berbasis silase KBK yang disuplementasi urea dan tepung ikan sebagai pengganti ransum berbasis rumput pada kambing.

\section{MATERI DAN METODE}

Ransum percobaan terdiri dari rumput atau silase KBK dan konsentrat. Biomassa KBK segar hasil panen pada hari yang sama dikumpulkan dari kebun kakao PTPN VIII Rajamandala Bandung. Silase KBK dibuat sesuai metode Puastuti \& Yulistiani (2011) dengan cara mencampur KBK segar yang dicacah dengan ukuran 1-2 cm dan dedak padi halus sebanyak 10\% sehingga diperoleh campuran dengan bahan kering sebesar 25-30\%. Campuran dimasukkan dalam kantong plastik tebal, dipadatkan dan diikat rapat untuk menciptakan kondisi anaerob dan disimpan minimal selama tiga minggu. Pembukaan silase KBK dilakukan sesaat sebelum diberikan pada ternak. Rumput yang digunakan adalah rumput Gajah segar yang dicacah dengan ukuran $\pm 5 \mathrm{~cm}$. Konsentrat standar disusun 
dari dedak halus, onggok, jagung, pollard, bungkil kedelai, molases dan mineral. Pada konsentrat perlakuan ditambahkan urea, tepung ikan dan campuran urea-tepung ikan, selengkapnya disajikan pada Tabel 1 .

Tabel 1. Susunan ransum percobaan

\begin{tabular}{|c|c|c|c|c|c|c|c|}
\hline \multirow{2}{*}{ Bahan Pakan } & \multicolumn{5}{|c|}{ Konsentrat } & \multirow{2}{*}{ Rumput } & \multirow{2}{*}{$\begin{array}{c}\text { Silase } \\
\text { KBK }\end{array}$} \\
\hline & $\mathrm{R}$ & $S$ & SU & SI & SUI & & \\
\hline Dedak (\%) & 31,00 & 31,00 & 31,00 & 30,00 & 29,00 & & \\
\hline Onggok (\%) & 17,00 & 17,00 & 16,00 & 14,00 & 15,00 & & \\
\hline Jagung (\%) & 15,00 & 15,00 & 15,00 & 15,00 & 17,00 & & \\
\hline Pollard (\%) & 17,00 & 17,00 & 17,00 & 16,00 & 16,00 & & \\
\hline Bungkil kedelai (\%) & 17,00 & 17,00 & 17,00 & 17,00 & 17,00 & & \\
\hline Mineral mix (\%) & 1,00 & 1,00 & 1,00 & 1,00 & 1,00 & & \\
\hline Molases (\%) & 2,00 & 2,00 & 2,00 & 2,00 & 2,00 & & \\
\hline Urea $(\%)$ & 0,00 & 0,00 & 1,00 & 0,00 & 0,50 & & \\
\hline Tepung ikan (\%) & 0,00 & 0,00 & 0,00 & 5,00 & 2,50 & & \\
\hline Total $(\%)$ & 100,00 & 100,00 & 100,00 & 100,00 & 100,00 & & \\
\hline \multicolumn{8}{|l|}{ Komposisi nutrien } \\
\hline $\mathrm{BK}(\%)$ & 83,42 & 83,42 & 82,56 & 83,42 & 82,56 & 91,69 & 93,32 \\
\hline PK $(\%)$ & 17,09 & 17,09 & 19,87 & 19,77 & 19,67 & 7,88 & 7,59 \\
\hline $\operatorname{ADF}(\%)$ & 22,84 & 22,84 & 23,44 & 21,99 & 21,47 & 46,1 & 51,01 \\
\hline $\mathrm{NDF}(\%)$ & 26,10 & 26,10 & 26,89 & 26,63 & 27,23 & 66,3 & 57,26 \\
\hline Energi kasar (kkal/kg) & 3.790 & 3.790 & 3.793 & 3.909 & 3.794 & 3.635 & 4.050 \\
\hline
\end{tabular}

Ransum percobaan disusun dari silase KBK atau rumput dan konsentrat dengan proporsi silase KBK atau rumput $50 \%$ dan konsentrat 50\%. Selengkapnya ransum percobaan adalah $\mathrm{R}=$ Rumput + konsentrat $\mathrm{R} ; \mathrm{S}=$ Silase KBK + konsentrat $\mathrm{S} ; \mathrm{SU}=$ Silase $\mathrm{KBK}+$ konsentrat SU; SI $=$ Silase $\mathrm{KBK}+$ konsentrat SI; dan SUI = Silase KBK + konsentrat SUI. Jumlah pemberian pakan didasarkan pada kebutuhan bahan kering sebanyak 3,5-4\% dari bobot hidup selama 10 minggu. Air minum disediakan sepanjang hari di dalam kandang. Pengujian ransum menggunakan sejumlah 20 ekor kambing jantan Peranakan Ettawah (PE) berumur antara 7-9 bulan dengan rata-rata bobot badan 20,7 $\pm 2,03$ $\mathrm{kg}$. Sebelum penelitian dimulai semua ternak diberi obat cacing dan vitamin B, kemudian ternak ditempatkan pada kandang individu. Kambing dikelompokkan berdasarkan bobot hidup dan setiap ekor kambing mendapatkan salah satu ransum dari lima perlakuan. Pada minggu akhir pengumpulan data dilakukan pengukuran kecernaan nutrien mengikuti metode koleksi total, dengan menempatkan kambing di dalam kandang metabolis yang dilengkapi tempat penampung feses dan urin. Pengumpulan sampel pakan/sisa pakan dan feses dilakukan selama 24 jam $\times 7$ hari berturut-turut. Sampel dianalisis bahan kering sesuai metode AOAC (1995), serat deterjen netral (SDN) dan serat deterjen asam (SDA) berdasarkan metode Van Soest et al. (1985). Pada hari terakhir dilakukan pengambilan sampel cairan rumen dengan stomach tube. Pengambilan dilakukan empat jam setelah pemberian pakan. Parameter $\mathrm{pH}$ cairan rumen diukur dengan $\mathrm{pH}$ meter, kadar VFA cairan rumen diukur dengan kromatografi gas dan $\mathrm{NH}_{3}$ diukur dengan metode Conwey. Percobaan ini dilakukan dengan menggunakan rancangan acak kelompok (RAK). Data 
yang diperoleh dianalisis sidik ragam menggunakan software SAS 9.1 (2002) dan perbedaan diantara perlakuan diuji Duncan.

\section{HASIL DAN PEMBAHASAN}

\section{Kecernaan bahan kering dan serat ransum berbasis KBK}

Nilai kecernaan ransum pada ternak dapat menggambarkan kualitas suatu ransum. Semakin tinggi nilai kecernaan menunjukkan ransum semakin mudah didegradasi di dalam rumen dan dicerna di pascarumen. Ransum berbasis silase KBK maupun yang disuplementasi urea, tepung ikan maupun campuran urea-tepung ikan menghasilkan kecernaan $\mathrm{BK}$ yang tidak berbeda nyata $(\mathrm{P}>0,05)$ dengan ransum berbasis rumput (Tabel 2). Nilai kecernaan yang serupa menggambarkan bahwa ransum berbasis KBK (S, SU, SI dan SUI) mampu memenuhi kebutuhan BK yang sebanding dengan ransum berbasis rumput (R). Nilai kecernaan BK dari ransum berbasis KBK pada penelitian ini 62,11$67,45 \%$ lebih tinggi dari penelitian sebelumnya yang memberikan silase KBK mengandung gamal dan kaliandra sebesar 44,6-57,5\% pada kambing (Puastuti et al. 2014) dan yang dilaporkan oleh Saili et al. (2010) yang memberikan KBK tanpa difermentasi maupun difermentasi dengan Aspergillus niger menghasilkan kecernaan BK sebesar 439$556 \mathrm{~g} / \mathrm{kg}$ atau $43,9-55,6 \%$ pada sapi Bali. Adanya suplemen tepung ikan dan campuran urea-tepung ikan pada ransum berbasis silase KBK (SI dan SUI) menyebabkan perbedaan nyata $(\mathrm{P}<0,05)$ pada kecernaan SDN dan SDA (Tabel 2) sehingga menyerupai nilai kecernaan ransum berbasis rumput $(\mathrm{R})$. Ransum $\mathrm{S}$ menghasilkan kecernaan BK yang lebih rendah 34,5\% dari ransum $\mathrm{R}$, namun bila dibandingkan dengan adanya suplemen tepung ikan dan campuran urea-tepung ikan (pada ransum SI dan SUI) mampu meningkatkan kecernaan SDN masing-masing sebesar 16,3 dan $26,4 \%$. Kenaikan yang nyata $(\mathrm{P}<0,05)$ juga dihasilkan dari kecernaan SDA. Terjadinya peningkatan kecernaan serat menunjukkan kecernaan berjalan lebih efektif oleh mikroba rumen dengan adanya tambahan sumber protein untuk pertumbuhan mikroba rumen. Hal ini sejalan dengan pernyataan peningkatan kecernaan serat sebagai akibat dari meningkatnya pertumbuhan bakteri sehingga proses fermentasi pakan dalam rumen berjalan lebih baik (Puastuti 2009).

Tabel 2. Kecernaan ransum berbasis KBK yang disuplementasi urea dan tepung ikan

\begin{tabular}{lccccc}
\hline \hline Perlakuan & $\mathrm{R}$ & $\mathrm{S}$ & $\mathrm{SU}$ & $\mathrm{SI}$ & SUI \\
\hline Kecernaan BK & $69,83^{\mathrm{a}} \pm 8,5$ & $64,03^{\mathrm{a}} \pm 8,0$ & $62,11^{\mathrm{a}} \pm 3,4$ & $64,98^{\mathrm{a}} \pm 9,1$ & $67,45^{\mathrm{a}} \pm 3,8$ \\
Kecernaan SDN & $48,08^{\mathrm{a}} \pm 10,5$ & $31,51^{\mathrm{b}} \pm 8,6$ & $30,67^{\mathrm{b}} \pm 5,8$ & $36,65^{\mathrm{ab}} \pm 13,3$ & $39,82^{\mathrm{ab}^{\mathrm{a}}} \pm 5,1$ \\
Kecernaan SDA & $53,37^{\mathrm{a}} \pm 5,2$ & $33,92^{\mathrm{b}} \pm 3,5$ & $32,73^{\mathrm{b}} \pm 3,7$ & $40,83^{\mathrm{ab}} \pm 5,8$ & $42,88^{\mathrm{ab}} \pm 1,9$ \\
\hline
\end{tabular}

Huruf berbeda pada baris yang sama menunjukkan berbeda nyata $(\mathrm{P}<0,05)$; $\mathrm{BK}$ : Bahan kering; SDN: Serat detergen netral; SDA: Serat deterjen asam; R: Rumput + konsentrat R; S: Silase KBK + konsentrat S; SU: Silase KBK + konsentrat SU; SI: Silase KBK + konsentrat SI; dan SUI: Silase $\mathrm{KBK}+$ konsentrat SUI

\section{Fermentabilitas ransum berbasis kulit buah kakao}

Produk fermentasi dari kecernaan protein dan sumber energi dalam rumen berupa amonia dan asam lemak volatile (VFA). Ransum berbasis rumput dan silase KBK baik yang ditambah urea, tepung ikan dan kombinasinya tidak menunjukkan adanya perbedaan produk VFA total maupun persentase komponennya $(\mathrm{P}>0,05)$ (Tabel 3). Nilai rata-rata VFA total berkisar 134,1-151,0 mM pada perlakuan ransum S, SU, SI, SUI dan sebesar 
$132,73 \mathrm{mM}$ pada ransum R. Keragaman yang tinggi dalam perlakuan merupakan salah satu penyebab nilai VFA tidak berbeda antar perlakuan. Keadaan ini lebih didominasi oleh pengaruh dari karakteristik individu ternak (Puastuti et al. 2014). Profil asam lemak individu juga menunjukkan pola yang serupa mulai dari asetat $(\mathrm{C} 2)$, propionat $(\mathrm{C} 3)$ dan butirat (C4). Perbedaan hanya terjadi pada iso valerat dimana pada ransum berbasis rumput menghasilkan kadar paling tinggi dibandingkan dengan ransum lainnya (Tabel 3). Asam lemak iso valerat (iC5) merupakan produk deaminasi dan dekarboksilasi dari asam amino bercabang di dalam rumen. Ransum berbasis rumput mengandung protein alami mudah didegradasi dibandingkan dengan ransum berbasis KBK terutama yang disuplementasi tepung ikan.

Tabel 3. Respon pemberian ransum terhadap $\mathrm{pH}, \mathrm{NH}_{3}$ dan konsentrasi VFA

\begin{tabular}{lccccc}
\hline \hline Parameter & $\mathrm{R}$ & $\mathrm{S}$ & $\mathrm{SU}$ & $\mathrm{SI}$ & SUI \\
\hline $\mathrm{pH}$ & $6,92^{\mathrm{a}} \pm 0,2$ & $6,89^{\mathrm{a}} \pm 0,1$ & $6,90^{\mathrm{a}} \pm 0,1$ & $7,02^{\mathrm{a}} \pm 0,2$ & $6,74^{\mathrm{a}} \pm 0,1$ \\
$\mathrm{NH}_{3}(\mathrm{mM})$ & $10,66^{\mathrm{a}} \pm 2,4$ & $7,79^{\mathrm{a}} \pm 3,4$ & $4,70^{\mathrm{b}} \pm 2,2$ & $5,21^{\mathrm{b}} \pm 1,8$ & $8,32^{\mathrm{ab}} \pm 2,9$ \\
VFA Total $(\mathrm{mM})$ & $132,73^{\mathrm{a}} \pm 33,3$ & $135,07^{\mathrm{a}} \pm 48,1$ & $141,55^{\mathrm{a}} \pm 19,7$ & $134,1^{\mathrm{a}} \pm 29,5$ & $151,0^{\mathrm{a}} \pm 45,5$ \\
$\mathrm{C} 2(\%)$ & $70,7^{\mathrm{a}} \pm 3,2$ & $71,3^{\mathrm{a}} \pm 5,9$ & $72,6^{\mathrm{a}} \pm 1,3$ & $73,7^{\mathrm{a}} \pm 2,2$ & $70,7^{\mathrm{a}} \pm 2,78$ \\
$\mathrm{C} 3(\%)$ & $14,3^{\mathrm{a}} \pm 0,9$ & $13,3^{\mathrm{a}} \pm 0,9$ & $15,1^{\mathrm{a}} \pm 0,8$ & $14,7^{\mathrm{a}} \pm 0,9$ & $16,5^{\mathrm{a}} \pm 5,4$ \\
$\mathrm{iC} 4(\%)$ & $1,7^{\mathrm{a}} \pm 0,5$ & $1,7^{\mathrm{a}} \pm 0,3$ & $1,7^{\mathrm{a}} \pm 0,7$ & $1,6^{\mathrm{a}} \pm 0,3$ & $1,4^{\mathrm{a}} \pm 0,3$ \\
$\mathrm{nC} 4(\%)$ & $10,9^{\mathrm{a}} \pm 0,7$ & $12,3^{\mathrm{a}} \pm 4,8$ & $9,9^{\mathrm{a}} \pm 1,6$ & $9,3^{\mathrm{a}} \pm 1,1$ & $10,4^{\mathrm{a}} \pm 2,9$ \\
$\mathrm{iC} 5(\%)$ & $1,6^{\mathrm{a}} \pm 0,6$ & $0,9^{\mathrm{b}} \pm 0,7$ & $0,5^{\mathrm{b}} \pm 0,1$ & $0,6^{\mathrm{b}} \pm 0,2$ & $0,7^{\mathrm{b}} \pm 0,4$ \\
$\mathrm{nC5}(\%)$ & $0,7^{\mathrm{a}} \pm 0,6$ & $0,5^{\mathrm{a}} \pm 0,7$ & $0,19^{\mathrm{a}} \pm 0,4$ & $0,1^{\mathrm{a}} \pm 0,16$ & $0,4^{\mathrm{a}} \pm 0,4$ \\
\hline
\end{tabular}

Huruf berbeda pada baris yang sama menunjukkan berbeda nyata $(\mathrm{P}<0,05)$; R: Rumput + konsentrat R; S: Silase KBK + konsentrat S; SU: Silase KBK + konsentrat SU; SI: Silase KBK + konsentrat SI; dan SUI: Silase KBK + konsentrat SUI

Tingkat degradasi protein di dalam rumen menghasilkan produk antara berupa amonia $\left(\mathrm{NH}_{3}\right)$. Kadar $\mathrm{N}^{-\mathrm{NH}_{3}}$ dipengaruhi oleh tingkat kelarutan protein ransum. Menurut Kalbande \& Thomas (2001) konsentrasi N-NH3 meningkat dengan semakin meningkatnya jumlah protein yang terdegradasi dan terlarut. Ransum dengan silase KBK yang mengandung tanin, memiliki tingkat degradasi protein yang lebih rendah dibandingkan dengan rumput yang tidak mengandung tanin. Kompleks tanin-protein menurunkan daya cerna, baik oleh mikroba rumen maupun enzim-enzim pencernaan (Firdus et al. 2004). Suplementasi tepung ikan merupakan sumber protein yang tahan degradasi, sebaliknya urea akan cepat didegradasi oleh mikroba di dalam rumen. Namun demikian, proses fermentasi di dalam rumen masih berjalan normal seperti yang ditunjukkan oleh kondisi keasaman cairan rumen. Dengan nilai $\mathrm{pH}$ cairan rumen yang serupa di antara kelima perlakuan $(6,74-7,02)$ menunjukkan proses fermentasi berjalan normal.

\section{KESIMPULAN}

Ransum berbasis silase KBK yang disuplementasi campuran urea-tepung ikan dapat menggantikan ransum berbasis rumput dengan kecernaan dan kemampuan menghasilkan energi yang setaraf. Penggunaan 50\% silase KBK dapat menggantikan keseluruhan rumput dalam ransum. 


\section{DAFTAR PUSTAKA}

AOAC.1995. Official methods of analysis. 16th ed. Arlington. (US): Association of Official Analytical Chemists.

Adamafio NA. 2013. Theobromine toxicity and remediation of cocoa by-product: An overview. J Biol Sci. 13:570-576.

Daud Z, Kassim ASM, Aripin AM, Awang H, Hatta MZM. 2013 Chemical composition and morphological of cocoa pod husks and cassava peels for pulp and paper production. Austr $\mathbf{J}$ Basic Appl Sci. 7:406-411.

Firdus A, Astuti DA, Wina E. 2004. Pengaruh kondisi fisik kaliandra dan campurannya dengan gamal segar terhadap konsumsi dan kecernaan nutrien pada domba. JITV. 9:12-16.

Hardana NE, Suparwi, Suhartati FM. 2013. Fermentasi kulit buah kakao (Theobroma cacao L) menggunakan Aspergillus niger pengaruhnya terhadap kecernaan bahan kering (KBK) dan kecernaan bahan organik (KBO) secara in vitro. J Ilmiah Peternakan. 1:781-788.

Kalbande VH, Thomas CT. 2001. Effect of feeding bypass on rumen fermentation profile of crossbred cows. Asian-Aust J Anim Sci. 14:974-978.

Mensah CA, Adamafio NA, Amaning-Kwarteng K, Rodrigues FK. 2012. Reduced tannin content of laccase-treated cocoa (Theobromine cacao) pod husk. Int J Biol Chem. 6:31-36.

Puastuti W, Widiawati Y, Wina E. 2014. Kecernaan dan fermentasi ruminal ransum berbasis silase kulit buah kakao yang diperkaya daun gamal dan kaliandra pada kambing. JITV. 20:31-40.

Puastuti W, Yulistiani D. 2011. Utilization of urea and fish meal in cocoa pod silage based rations to increase the growth of Ettawah crossbreed goats. In: Ali Agus, Kamil KA, Alimon AR, Orskov, Zentek J, Tanuwiria UH, editors. Feed Safety for Healty Food. Proceeding The 2nd International Seminar. Bandung (Indonesia): AINI Publication. p. 463-469.

Puastuti, W. 2009. Manipulasi bioproses dalam rumen untuk meningkatkan penggunaan pakan berserat. Wartazoa. 19:180-190.

Puastuti W, Susana IWR. 2014. Potensi dan pemanfaatan kulit buah kakao sebagai pakan alternatif ternak ruminansia. Wartazoa. 24:151-159.

Rinduwati, Ismartoyo. 2002, Karakteristik degradasi beberapa jenis pakan (in sacco) dalam rumen ternak kambing. Buletin Nutrisi dan Makanan Ternak. 31:1-14.

Saili T, Marsetyo, Poppi DP, Isherwood, Nafiu L, Quigley SP. 2010. Effect of treatment of cocoa pod with Aspergillus niger on liveweight gain and cocoa pod in take Bali (Bos sondaicus) cattle in South East Sulawesi. Anim Prod Sci. 50:693-698.

SAS. 2002. SAS/STAT user's guide. Version 9.1. North Carolina (US): SAS Institute Inc.

Van Soest PJ. 1985. Definition of fiber animal feed. In: Recent Advances in animal nutrition. Heresign, Wand DJA, Cole, editors. London (UK): Butterworths. p.113-129.

Zain M. 2009. Substitusi rumput lapangan dengan kulit buah cokelat amoniasi dalam ransum domba lokal. Media Peteternakan. 32:47-52. 